\title{
Temporomandibular disorder pain improvement with acupuncture: preliminary longitudinal descriptive study*
}

\author{
Redução da dor da disfunção temporomandibular com acupuntura: estudo descritivo \\ longitudinal preliminar
}

Bruna Angeleli Bueno de Camargo, Cássia Maria Grillo, Maria da Luz Rosário de Sousa1
${ }^{*}$ Received from Dentistry School of Piracicaba, State University of Campinas. Piracicaba, SP, Brazil.

DOI 10.5935/1806-0013.20140035

\section{ABSTRACT}

BACKGROUND AND OBJECTIVES: Acupuncture is a therapeutic method widely used to manage pain. Temporomandibular disorders have symptoms such as facial pain, pain in temporomandibular region and in masticatory muscles. This study aimed at describing the results obtained in temporomandibular disorder pain intensity improvement in patients treated in a public service with a minimum number of three acupuncture sessions. METHODS: This is a descriptive study with patients with temporomandibular disorders treated in the Dentistry Specialties Center I of the city of Piracicaba (SP) in the period from September 2010 to October 2011. Sample was made up of 31 patients of both genders, aged between 14 and 68 years. Pain was measured by the visual analog scale (VAS), called initial VAS (pre-treatment) and final VAS (post-treatment), respectively in the beginning and end of the acupuncture session. Each patient was submitted to three 20-minute sessions, once a week.

RESULTS: Pain was absent (VAS=0) in $67.7 \%$ of patients who had pain intensity improvement with iVAS in the first session higher $(6.10 \pm 2.64)$ than fVAS in the third session (1.16 \pm 1.98$)$.

CONCLUSION: With a minimum of three weekly acupuncture sessions it was possible to control temporomandibular disorder pain regardless of the level of initial pain. Its use could contribute to enhance the treatment of such patients in the public service for being a low cost and easy to apply therapy.

Keywords: Acupuncture therapy, Facial pain, Temporomandibular disorder.

1. Dentistry School of Piracicaba, Piracicaba, SP, Brazil.

Submitted in January 27, 2014.

Accepted for publication in July 18, 2014.

Conflict of interests: none.

Correspondence to:

Maria da Luz Rosário de Sousa

Av. Limeira, 901 - Areấo

13414-903 Piracicaba, SP, Brasil.

E-mail: luzsousa@fop.unicamp.br

(C) Sociedade Brasileira para o Estudo da Dor

\section{RESUMO}

JUSTIFICATIVA E OBJETIVOS: Acupuntura é um método terapêutico e seu uso é amplo para o tratamento da dor. As disfunções temporomandibulares apresentam sintomas como dores na face, na região da articulação temporomandibular, nos músculos mastigatórios. $\mathrm{O}$ objetivo deste estudo foi descrever os resultados obtidos na redução da intensidade de dor na disfunção temporomandibular em pacientes atendidos no serviço público com um número mínimo de três sessôes de acupuntura.

MÉTODOS: Trata-se de estudo descritivo de pacientes com disfunção temporomandibular tratados com acupuntura no Centro de Especialidades Odontológicas I do município de Piracicaba (SP), no período de setembro de 2010 a outubro de 2011. A amostra foi de 31 pacientes, de ambos os gêneros, com idade entre 14 e 68 anos. A dor foi mensurada através da escala analógica visual (EAV), denominada EAV inicial (pré-tratamento) e EAV final (pós-tratamento), respectivamente no inicio e ao final da sessão de acupuntura. Cada paciente recebeu três sessóes de acupuntura, uma vez por semana com a duração de 20 minutos.

RESULTADOS: A dor cessou (EAV=0) em 67,7\% dos pacientes que apresentaram redução na intensidade de dor, com EAVi da $1^{\text {a }}$ sessão maior $(6,10 \pm 2,64)$ do que a EAVf da $3^{\text {a }}$ sessão $(1,16 \pm 1,98)$.

CONCLUSÃO: Com um número mínimo de três sessôes semanais de acupuntura foi possível o controle da dor em pacientes com disfunção temporomandibular independentemente do grau de dor inicial. Sua utilização poderia contribuir para ampliar o atendimento a esses pacientes no serviço público por ser uma prática terapêutica de baixo custo e fácil aplicação.

Descritores: Articulação temporomandibular, Dor facial, Terapia por acupuntura.

\section{INTRODUCTION}

Acupuncture is a therapeutic method part of the Traditional Chinese Medicine (TCM). It is millennial being used for 5 thousand years in Eastern countries and having been incorporated to other countries such as Japan, Korea and Vietnam. It appeared in Brazil when Japanese immigrants came to work in coffee plantations approximately 100 years ago ${ }^{1}$.

Acupuncture is based on the stimulation of specific anatomic body points, called acupoints, to prevent, reestablish or main- 
tain health. Needling is the most common therapeutic practice with acupuncture, but in addition to heat (moxa), acupuncture points may be stimulated with laser, electricity (electroacupuncture) and with suction cups ${ }^{2}$.

According to a study ${ }^{2}$, one advantage of using acupuncture is that it is effective to treat pain, especially musculoskeletal pain, being that in dentistry, temporomandibular disorders (TMD) or craniomandibular disorders (CMD) are the most common types of orofacial musculoskeletal pain ${ }^{3}$.

TMDs represent a heterogeneous group of problems characterized by orofacial pain and/or masticatory dysfunction ${ }^{4}$; they have symptoms such as pain in face, in temporomandibular joints (TMJ) region, in masticatory muscles, in head and ear and some otologic manifestations such as tinnitus, vertigo and ear fullness ${ }^{5}$.

Due to the similarity of TMDs with other musculoskeletal disorders, where part of the natural course of such alterations is unknown, conservative therapies are indicated as treatment, including pharmacological agents, self-massage, patients' education and self-care, physical therapy, occlusal adjustments, occlusal splints and acupuncture ${ }^{3}$.

According to a study ${ }^{5}$, there are few public policies to disclose the disease and treat individuals with TMD and, in this case, acupuncture could contribute to expand the care to those patients for being a low cost and easy to apply therapeutic practice.

In light of the above, this study aimed at describing the results obtained to decrease TMD pain intensity in patients treated with acupuncture in the public service, with a minimum number of three sessions.

\section{METHODS}

For being a study with human beings, it was carried out according to ethical principles and according to resolution 196/96 of the National Health Council of the Ministry of Health, in compliance with the Declaration of Helsinki and was only started after the signature of the Free and Informed Consent Term (FICT).

This is a preliminary longitudinal descriptive study because sample is small and there is no control group. Sample was made up of 31 acupuncture patients from the Dentistry Specialties Center I (CEO) from the city of Piracicaba (Sáo Paulo) in the period from September 2010 to October 2011, aged between 14 and 68 years, from both genders, with diagnosis of muscular TMD who were referred for treatment with acupuncture with painful symptoms in face, with pain in TMJ region and in other sites. They were treated with three acupuncture sessions. Before (pre-treatment) and after (post-treatment) each acupuncture session, patients would check the level of pain intensity they felt in the visual analog scale (VAS) (initial VAS - iVAS and final VAS - fVAS).

From total sample $(n=31), 83.87 \%$ were females and most patients were between 30 and 49 years of age $(51.61 \%)$, followed by those with 50 years of age or above $(25.81 \%)$.

Patients were treated with traditional acupuncture, in week- ly sessions lasting 20 minutes. Skin was cleaned with cotton soaked in $70 \%$ alcohol. Needles were Chinese, sterilized, disposable and individually packaged, in the sizes of $0.20 \times 13 \mathrm{~mm}$ for facial points and $0.25 \times 30 \mathrm{~mm}$ for points far from the face, from the Qizhou brand (Wujiang City Shenli Medical \& Health Material Co. Ltd). Insertion and depth were according to the literature ${ }^{6}$, respecting physical constitution, age and location of the point ${ }^{7}$. Needles were manually inserted and rotated clockwise and counterclockwise until patients reported deqi sensation ${ }^{8}$. Insertion was unilateral (Figure 1), at the side of the most severe pain and after obtaining deqi the needles were no longer manipulated (sedation or tonification) ${ }^{9}$.

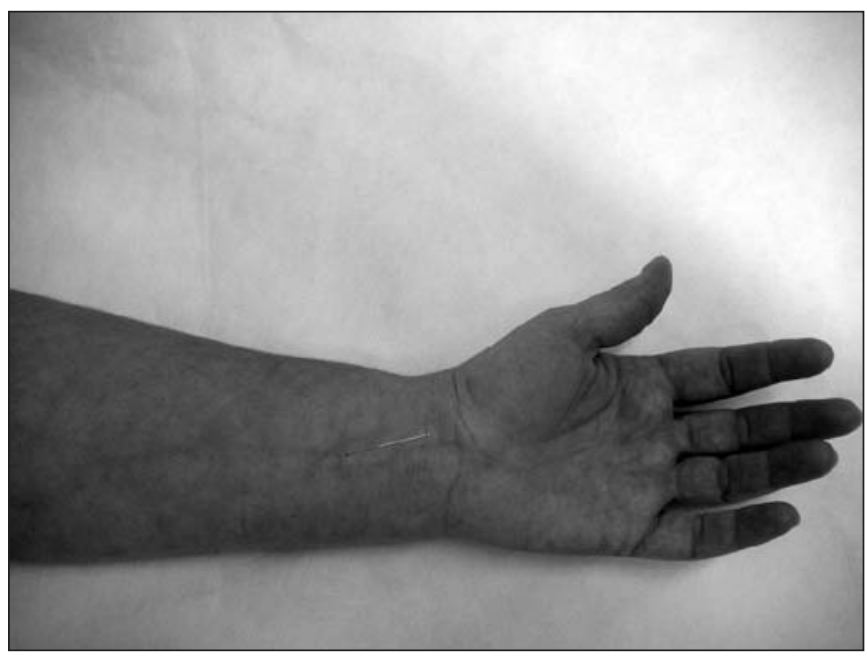

Figure 1. Needle inserted in the CS6 point (Neiguan)

Patients' report about deqi was observed at each insertion, which is a specific sensation felt when a needle is inserted in the acupuncture point and may present as pain, numbness, heat, weight or distension around the area where the needle was inserted. It may irradiate along the pathway of the meridian to which the stimulated point belongs. This is a desired and necessary effect for acupuncture to be effective ${ }^{10}$.

Acupuncture was performed by dentists qualified in acupuncture by the Federal Council of Dentistry, who are part of the Acupuncture Group, Dentistry School of Piracicaba - FOP/ UNICAMP and who are volunteers in the CEO. Patients of the research were referred to acupuncture treatment with diagnosis of muscular TMD, which is one indication for the use of acupuncture ${ }^{3}$, by a dentist specialized in buccomaxillofacial surgery who works at the same place and makes the referral to acupuncture treatment.

Through initial patients' history with questions such as preference for heat or cold, location and type of pain (throbbing, heavy, stabbing), tongue and pulse inspection, the energy imbalance was located and, based on the clinical experience of the group, a set of points was selected for treatment, being the following the most common:

Emotional Rebalance: C7 (Shenmen), CS6 (Neiguan), ID3 (Houxi), VB20 (Fengchi) and TA23 (Sizhukong). Related to the presence of anxiety and emotional problems ${ }^{11}$.

Kidney Yin defficiency with alteration of Chong Mai Me- 


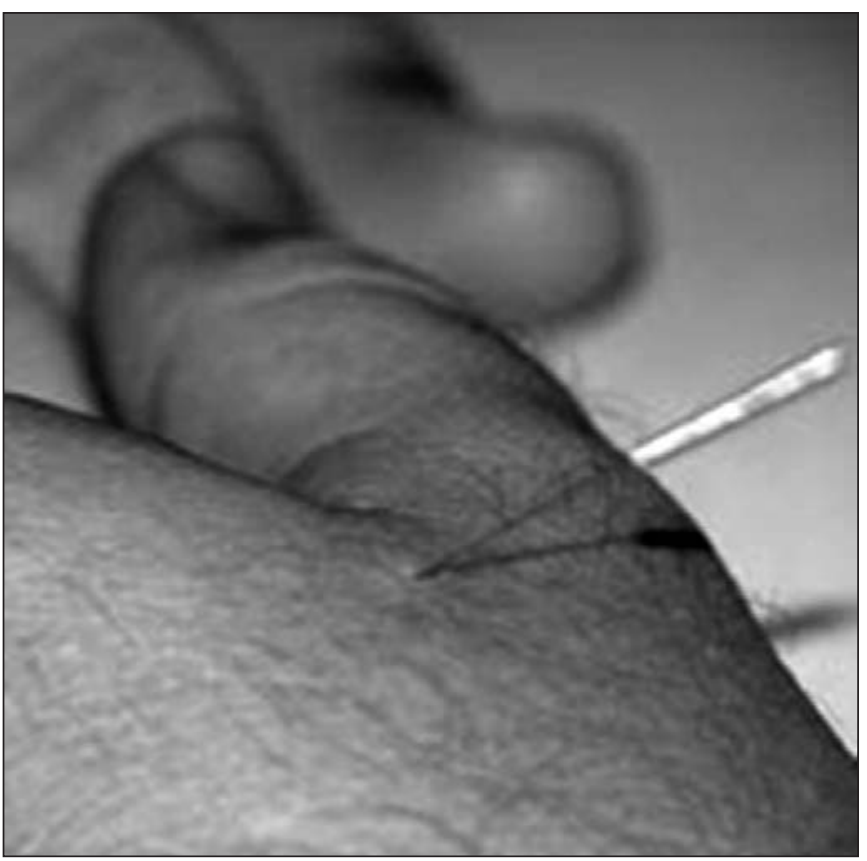

Figure 2. Needle inserted in point IG4 (Hegu)

ridian energy: VC 3 (Zhongji), R3 (Taixi), R7 (Fuliu), VG4 (Mingmen), VG14 (Dazhui), TA17 (Yfeng) and TA21 (Ermen). In cases of energy wear ${ }^{12}$.

Ascension of kidney Yang with internal wind: R7 (Fuliu), VB20 (Fengchi), VB34 (Yanglingquan), VB 39 (Xuanzhong), TA17 (Yfeng), F2 (Xingjian). In cases of thready pulse and presence of tongue or facial trembling ${ }^{13}$.

Spleen/pancreas Yang defficiency: VC12 (Zhongwan), TA3 (Zhongzhu), IG4 (Hegu) (Figura 2), BP4 (Gongsun) and VG15 (Yamen). In cases of insomnia, concern, teeth marks on the side of the tongue ${ }^{14}$.

For statistical analysis, $t$ test for related samples was used, with evaluation of iVAS (before each acupuncture session) and fVAS (after each acupuncture session). Significance level was $\mathrm{p}<0.05$. Program used was Bioestat 5.3.

The study was approved by the Research Ethics Committee, Dentistry School of Piracicaba/UNICAMP, under number 099/2008.

\section{RESULTS}

Pain disappeared $(\mathrm{VAS}=0)$ in $67.7 \%$ of patients and was improved for remaining patients. In all sessions, mean fVAS was significantly lower than mean iVAS (Table 1). However, there has been VAS variation between sessions, when some patients had increased pain intensity after beginning the treatment. According to the literature ${ }^{6}$, painful symptoms may be exacerbated after acupuncture sessions because the evolution of patients treated by acupuncture is in cycles of improvement or worsening of clinical symptoms which are directly related to the evolution of the therapy itself or to the aggression of emotional factors (such as anger, fear, sadness) or extrinsic factors (such as weather conditions, traumas, etc.).
Table 1. Mean and standard deviation of initial and final pain intensity of each one of the three acupuncture sessions

\begin{tabular}{llllll}
\hline Session & Mean iVAS & SD & Mean fVAS & SD & p value \\
\hline $1^{\text {st }}$ & 6.10 & 2.64 & 2.74 & 2.26 & $<0.0001$ \\
$2^{\text {nd }}$ & 3.93 & 3.67 & 1.74 & 2.41 & $<0.0001$ \\
$3^{\text {rd }}$ & 2.55 & 3.27 & 1.16 & 1.98 & 0.0008 \\
\hline
\end{tabular}

VAS: visual analog scale; SD: standard deviation.

No adverse effect was observed during acupuncture sessions, regardless of pain intensity.

\section{DISCUSSION}

Results of this preliminary study show that three acupuncture sessions were effective to decrease pain intensity and that acupuncture is a safe method. Since patients have reported different responses to acupuncture, it is difficult to specify how many sessions are needed or which should be the treatment duration ${ }^{15}$ For chronic pain, in most cases there is the need for ten sessions, preferably in alternated days, or once a week ${ }^{2}$ to obtain long-lasting benefits.

It is known that TMDs are the most common type of orofacial musculoskeletal pain and when presented as chronic pain are difficult to be controlled by dentists or other health professionals ${ }^{3}$. They cause discomfort and decrease people's ability, because as well as pain, functional jaw limitation brings significant problems to patients who find difficulties to perform daily activities such as eating, expressing themselves, talking, working, etc. ${ }^{4}$.

Acupuncture is used to treat TMD pain and other associated symptoms ${ }^{16}$. It is effective to relieve muscular pain and has the advantage of decreasing local inflammatory process, thus relieving pain, but in addition to relieving pain, one or more acupuncture sessions have benefits for general health, such as better fitness, better sleep patterns, appetite improvement and a sensation of well-being ${ }^{15}$, which are strategies to treat TMD based on decreasing symptoms and improving function and quality of life $e^{4}$.

Acupuncture action mechanism is still not explained. When the needle is inserted in the skin, a pain control system is activated to inhibit pain signals entering the nervous system. This control system is called analgesia system, which induces the secretion of endogenous opioids and the involvement of neurotransmitters (endorphin, encephalin and serotonin) ${ }^{17}$. Western theories are especially based on the fact that acupuncture induces signals in afferent nerves which modulate the transmission of the signal in the spine and pain perception in the brain $^{18}$.

According to TCM, based on energy imbalance, pain is interpreted as a stagnation of Qi (energy) and/or Xue (blood), and acupuncture aims at removing such stagnation and at regulating Qi flow in energy channels (Meridians) ${ }^{19}$. Based on this, already described protocols were used, each one indicated for an imbalance identified in TMD patients in the clinical practice. This study has observed that they are effective to control pain intensity. Among points, the IG4 point (Figure 2) is to 
be highlighted for having strong analgesic action ${ }^{19}$ and being widely used in dentistry (although being located in the hand), which presents very favorable results to manage orofacial pain. An explanation for such is its internal pathway closely related to the oral cavity?.

A study ${ }^{20}$ has compared acupuncture to occlusal splint in females with TMD, where the acupuncture group had better results in increasing mouth opening, since acupuncture is able to relax masticatory muscles and one of its advantages is the possibility of being associated to conventional therapies. Our study has used acupuncture alone, which decreases public service costs.

In a different double blind study ${ }^{21}$ using acupuncture to treat TMD symptoms, a group has received real acupuncture and the other placebo acupuncture. The group treated with real acupuncture had pain improvement with significant difference as compared to placebo acupuncture, results which were also obtained in this study regardless of initial pain intensity.

Our study has not observed any adverse effect, although the literature ${ }^{22}$ has reported mild adverse effects such as sweating, vertigo and bleeding in 7 to $11 \%$ of patients. The possibility of not having adverse effects may be the fact that patients were referred by a previous screening of a professional know by them, in the same place where acupuncture sessions are carried out, improving confidence/safety for this type of treatment.

One should stress that the treatment is safe, if provided by a qualified professional. Acupuncture is still not a dentistry specialty; in 2008 it was recognized by the Federal Council of Dentistry, which has created the Qualification in acupuncture for dentists, thus the importance of being a dentistry specialty. Our results indicate that acupuncture is an option to treat patients with muscular TMD, because it acts not only to control pain but also brings benefits for general health, which reflects the biopsychosocial health model.

This study had some limitations: the first is the sample size which was small to totally evaluate the effects of the treatment; the second is that there is no control group and so, Sham acupuncture was not used. For future studies, we suggest randomized studies including control group to check specific acupuncture effects and treatment indications, expanding it use both in private and public health services.

\section{CONCLUSION}

With a minimum of three weekly acupuncture sessions it was possible to control TMD patients' pain, regardless of initial pain intensity. Its use could contribute to expand the treatment of TMD patients in the public service for being a low cost and easy to apply therapeutic practice.

\section{ACKNOWLEDGMENTS}

To the Health Department of the City of Piracicaba, for the support.

\section{REFERENCES}

1. Vianna RS, Souza AG, Silva BC, Berlinck TA, Dias KR. A acupuntura e sua aplicação na Odontologia. Rev Odontol. 2008;10(4):48-52.

2. Pai HJ, Dias MH, Hosomi JK, Andrade MP. Acupuntura médica: princípios básicos e aspectos atuais na prática clínica. Rev Dor. 2006;7(2):774-84.

3. Branco CA, Fonseca RB, Oliveira TR, Gomes VL, Fernandes Neto AJ. Acupuntura como tratamento complementar nas disfunçōes temporomandibulares: revisão de literatura. Rev Odontol UNESP. 2005;34(1):11-6.

4. Alajbeg I. Temporomandibular disorders - the role of neuromuscular dentistry. Med Scien. 2010;34:33-41.

5. Carrara SV, Conti PC, Barbosa JS. Termo do $1^{\circ}$ Consenso em Disfunçấo Temporomandibular e Dor Orofacial. Dental Press J Orthod. 2010;15(3):114-20.

6. Yamamura Y. A arte de inserir. 2a ed. São Paulo: Roca; 2004. 646-7p.

7. Lu DP, Lu GP. Anatomical relevance of some acupuncture points in the head and neck region that dictate medical or dental application depending on depth of needle insertion. Acupuncture Electrother Res. 2003;28(3/4):145-56.

8. Kang KW, Kim WY, Kim TH, Shin BC, Jung SY, Kim AR, et al. Adjacent, distal, or combination of point-selective effects of acupuncture on temporomandibular joint disorders: A randomized, single-blind, assessor-blind controlled trial. Integr Med Res. 2012;1(1):36-40.

9. Grillo CM, Wada RS, Sousa ML. Acupuncture in the management of acute dental pain. J Acupunct Meridian Stud. 2013;7(2):65-70.

10. Chernyak GV, Sessler DI. Perioperative acupuncture and related techniques. Anesthesiolgy. 2005;102(5):1031-78.

11. Grillo CM, Zotelli, VL, Meirelles, MP, Sousa ML. Efetividade da acupuntura no controle de dor em pacientes com disfunçáo temporomandibular. Rev Paul Odontol. 2013;35:31-5.

12. Fortinguerra ML, Grillo CM, Rando-Meirelles MP, Sousa ML. Disfuçăo temporomandibular: acupuntura como tratamento alternativo. Relato de caso. Rev Paul Odontol. 2011;33:19-3.

13. Rui A, Meirelles MP, Sousa ML. Relato de caso sobre o uso da acupuntura no tratamento da dor orofacial. Arq Ciênc Saúde UNIPAR. 2011;15(3):287-90.

14. Zotelli VL, Rando-Meirelles MP, Sousa ML. Uso da acupuntura no manejo da dor em pacientes com alteraçôes na articulaçấo temporomandibular (ATM). Rev Odontol UNICID. 2010;22:185-8.

15. Mangal B, Sugandhi A, Kumathalli KI, Sridhar R. Alternative medicine in periodontal therapy - a review. J Acupunct Meridian Stud. 2012;5(2):51-6.

16. Itoh K, Asai S, Ohyabu H, Imai K. Effects of trigger point acupuncture treatment on temporomandibular disorders: a preliminary randomized clinical trial. J Acupunct Meridian Stud. 2012;5(2):57-62.

17. Cabýoglu MT, Ergene N, Tan U. The mechanism of acupuncture and clinical applications. Int J Neurosci. 2006;116(2):115-25.

18. Wang SM, Kain ZN, White P. Acupuncture analgesia: I. The scientific basis. Anesth Analg. 2008;106(2):602-10.

19. Noiman M, Garty A, Maimon Y, Miller U, Lev-Ari S. Acupuncture for treating temporomandibular disorder: retrospective study on safety and efficacy. J Acupunct Meridian Stud..2010;3(4):260-6.

20. Alves-Rezende MC, Sant'Anna CB, Ávila de Aguiar SM, Bertoz APM, Hall KB, Dyonísio AL, et al. Temporomandibular disorders in females: acupuncture compared to occlusal splint. Arch Health Invest .2013;2(3):8-14.

21. Smith P. Mosscrop D, Davies S, Sloan P, Al-Ani Z. The efficacy of acupuncture in the treatment of temporomandibular joint myofascial pain: a randomized controlled trial. J Dent. 2007;35(3):259-67.

22. Ernst E. Acupuncture--a critical analysis. J Intern Med. 2006;259(2):125-37. 